\title{
Para uma Análise dos Festivais de Cinema em Portugal: Génese, institucionalização e desafios
}

\author{
Tânia Leão \\ Instituto de Sociologia da Universidade do Porto \\ Email: tsilva@letras.up.pt \\ https://orcid.org/0000-0003-1670-075X
}

RESUMO Este ensaio propõe analisar o nascimento e evolução dos festivais de cinema, em Portugal, a partir de duas orientações principais: (i) efetuando uma revisão da literatura que permita identificar as principais lacunas existentes sobre a matéria e apontar possibilidades de pesquisa; e (ii) desenvolvendo um itinerário analítico diacrónico, complementado por múltiplas dimensões de análise, para sublinhar a complexidade de que se reveste o fenómeno dos festivais de cinema (enformado por fatores históricos, políticos, económicos, sociais, territoriais / espaciais e culturais). 0 texto procura, assim, discutir a relação entre essas múltiplas dimensões que, de forma dialogante, contribuem para uma análise interpretativa do modo como tem evoluído o fenómeno em Portugal: a conexão entre, por um lado, a gradativa proliferação de festivais de cinema e, por outro, as transformações nos espaços de exibição cinematográfica, as mudanças nas políticas públicas para o cinema (particularmente, na legislação aplicável ao circuito alternativo de exibição), e a crescente perceção dos festivais como fatores de desenvolvimento local; a reconfiguração dos circuitos de consumo/ fruição de cinema, com o agravamento das assimetrias territoriais na oferta cinematográfica; e a preservação da importância dos festivais de cinema enquanto contextos decisivos para a criação e manutenção de comunidades cinéfilas, espaços de reunião de intermediários culturais e profissionais do setor, e agentes dinamizadores da cinefilia e da cultura cinematográfica do país.

PALAVRAS-CHAVE Estudos sobre festivais de cinema; festivais de cinema em Portugal; políticas públicas; circuitos de exibição; comunidades cinéfilas.

Num dos textos inaugurais da recente vaga multidisciplinar de estudos sobre festivais de cinema, Marijke de Valck (2007) sugeriu que o contexto europeu de festivais de cinema fosse dividido em três fases. A primeira fase seria marcada pelo advento dos festivais de cinema: ia do estabelecimento do primeiro festival regular em Veneza (1932), passava pelo nascimento do festival de Cannes (em reação ao cariz eminentemente fascista e nacionalista do certame italiano), atravessava as disrupções experienciadas 
em Cannes e Veneza, por volta de 1968, e findava com a reorganização do formato festival, no início dos anos 1970. A segunda fase distinguira-se pela multiplicação dos festivais organizados de forma independente, que atuavam, ao mesmo tempo, como guardiões da arte cinematográfica e das comunidades cinéfilas e como facilitadores da indústria do cinema. E, finalmente, uma terceira fase, iniciada em meados da década de 1980, a que corresponderia o fenómeno de internacionalização, institucionalização e profissionalização dos festivais, dando origem ao que se convencionou chamar de circuito internacional de festivais de cinema. À semelhança de De Valck, Cindy Wong $(2011,37-63)$ destacou três períodos principais na biografia dos festivais de cinema, mas acrescentou-lhes subdivisões internas, e incluiu, na sua reflexão, o papel desempenhado por diversas instituições e movimentos (fundamentalmente cineclubes, mas também museus e arquivos), bem como os efeitos da racionalidade empresarial aplicada aos eventos e instituições culturais. Já Vallejo (2014, 33-35) acrescentou à tripartição histórica definida por De Valck uma quarta fase, a atual, que teria tido início na viragem do século. Segundo a autora, começou a assistir-se a uma saturação do circuito internacional de festivais de cinema, assinalada por tendências como a transferência dos custos dos festivais para os seus participantes (públicos, autores), a banalização e perda de influência dos certames, e a sua hipersegmentação e especialização, resultante do acréscimo de secções industriais.

Portugal não replicou integralmente as grandes tendências alinhavadas por estas autoras, nisso refletindo a advertência lançada por Vallejo, para quem, mesmo sendo os festivais de cinema um fenómeno resultante de "processos de transferência, normalmente por imitação e transposição de modelos já visitados", não seria expectável que os diferentes países passem "pelas mesmas fases no mesmo período" (2014: 35). Assim, tendo por objeto de análise os festivais de cinema portugueses, o presente ensaio propõe-se atingir dois objetivos principais: (i) realizar um esboço da génese e evolução dos festivais de cinema, em Portugal, com vista a sinalizar lacunas, desafios e possibilidades de pesquisa; e (ii) estimular pesquisas futuras, salientando as vantagens de um modelo de análise diacrónico e multidimensional para o estudo dos festivais de cinema. 0 texto resulta de um exercício exploratório e pretende sublinhar a complexidade deste objeto de estudo, que, como alerta De Valck (2016a: 9), é um fenómeno "com braços de polvo que atravessa os domínios da cultura, economia e política". Não se ambiciona explorar a fundo todas estas dimensões, mas demonstrar como a compreensão dos festivais de cinema remete para distintos níveis de análise. Argumentamos que os festivais compõem um fenómeno 
sociocultural com características de "facto social total" - conceito cunhado por Marcel Mauss (1985) para se referir aos fenómenos que são irredutíveis a uma única dimensão do real social. Assumir a sua diversidade é, pois, o primeiro passo para os conhecer, ao que se segue a imprescindível circunscrição de quadros teórico-metodológicos específicos que garantam a exequibilidade das pesquisas a desenvolver.

A estratégia assumida para situar e analisar os festivais de cinema nacionais foi a de esboçar um itinerário cronológico dos acontecimentos que contribuíram para o seu aparecimento/ desaparecimento e evolução, aliada a uma visão interpretativa sobre o modo como diferentes dimensões atuaram e influíram no desenvolvimento deste fenómeno de grande complexidade. É o caso dos contextos histórico, político, económico, social, territorial/ espacial e cultural, e do seu papel na (re)organização da exibição de cinema em Portugal, com especial enfoque para a evolução da teia de festivais de cinema. ${ }^{1}$ Note-se que a tentativa de mapeamento histórico do nascimento e evolução dos festivais de cinema em Portugal é dificultada pela existência de uma imensa lacuna informacional, que pode ser entendida em dois níveis ou patamares: por um lado, os dados oficiais, estatísticos, sobre as esferas da distribuição, exibição e consumo de cinema em território nacional, são muito frágeis, quase inexistentes (em especial, no que toca ao circuito de exibição alternativo); por outro lado, a produção de conhecimento académico nesta área tem sido pouco sistemática e extremamente fragmentada.

Com efeito, o estudo da dimensão da circulação do cinema tem sido recorrentemente adiado em Portugal, apesar dos inúmeros alertas para a inquietante omissão, primeiro, pela voz de personalidades como os professores e ensaístas Eduardo Prado Coelho (1983) e João Bénard da Costa (1986) e, décadas mais tarde, no trabalho de numerosos investigadores/as, em campos que vão da história, à economia e sociologia. São disso exemplo Abreu e Mantecón (2013), quando comparam a reorganização da esfera da exibição cinematográfica em Portugal e no México; Avelar (2013), ao analisar a distribuição de cinema português no espaço europeu; Barbosa (2015), ao tentar construir uma ferramenta metodológica para mapear e caracterizar a exibição não comercial de

\footnotetext{
1 Nos casos em que, nas menções aos festivais de cinema, não são assinaladas referências bibliográficas, as fontes de informação foram páginas da internet (quase sempre, páginas oficiais dos festivais), devidamente elencadas na bibliografia final.
} 
cinema em Portugal; Costa (1999), na reflexão que faz sobre a distribuição e exibição de cinema europeu, em Portugal, nos anos 70; Cunha (2016), ao analisar a distribuição e exibição de cinema independente no país; Santos et al (1998), no seu estudo de referência sobre políticas culturais em Portugal; ou Neves e Santos (2011), na avaliação que fazem das estatísticas do Ministério da Cultura, entre vários outros, que realçam um vazio que tem dificultado a investigação desenvolvida neste campo.

As esferas a montante e a jusante - da criação e do consumo/ receção têm sido as mais aprofundadas. Na última década, a tarefa de decifrar o enigma que (ainda hoje) constitui a circulação de cinema em Portugal passou a suscitar um interesse mais amplo entre investigadores/as, em parte, devido à iniciativa estatal para produzir estatísticas oficiais dedicadas a essa dimensão. Entre as pesquisas desenvolvidas em torno dos festivais de cinema é possível referir alguns trabalhos recentes: Dias (2009), que estudou o festival IndieLisboa, centrando-se na programação e no posicionamento do certame enquanto divulgador de cinema 'independente'; Leão (2006, 2019), que investigou as comunidades de públicos, as apropriações rituais e simbólicas, e os modos de relação com os festivais e com a sua oferta programática no Fantasporto, no Curtas de Vila do Conde e no IndieLisboa; Araújo (2013), que realizou uma análise motivacional para compreender as motivações de participação dos públicos do IndieLisboa e do Fantasporto; Ramos (2010), que analisou a importância do Curtas Vila do Conde para a dinamização e projeção da cidade nortenha, e o seu impacto na política cultural local; Almeida (2013), que avaliou a capacidade dos festivais de cinema nacionais situados fora dos principais centros urbanos para atrair turistas; Vale (2013), que refletiu sobre a nova vaga de festivais de cinema de Lisboa, a partir de uma perspetiva que enfatiza o seu papel como fatores de desenvolvimento social e económico; Ferreira (2018), que avaliou as políticas públicas de financiamento aos festivais de cinema portugueses, centrando-se nos certames apoiados pelo ICA entre 2015 e 2017; Carrilho (2008) que analisou as estruturas de produção de documentários portugueses presentes nas edições iniciais do Doclisboa; ou Alves (2018), que partiu também do Doclisboa para avaliar as suas estratégias de comunicação e divulgação. As pesquisas disponíveis sobre festivais de cinema são, quase sempre, estudos de caso, ou, em alternativa, focadas em intervalos temporais curtos. Concentram-se maioritariamente nos festivais recentes, apoiados pelo Estado e situados nas principais cidades. Há, ainda, um interesse crescente pelo impacto dos festivais de cinema no desenvolvimento do território e na criação de riqueza. 
O exercício de reflexão que aqui aventamos permitiu concluir que o caso português se reveste de singularidades. Os festivais de cinema não têm sido apenas (ou sequer sempre) eventos cinematográficos a funcionar em paralelo ao sistema de distribuição e exibição comercial. São também, por um lado, instâncias de reprodução do poder e da ordem vigentes, ou, em alternativa, contextos de inovação e de reconfiguração social, política e cultural. Servem, ainda, para preservar a dimensão social e simbólica do consumo de cinema, podendo exercer um papel, determinante, de mediação cultural e de definição da cultura cinematográfica nacional.

\section{Do movimento cineclubista português aos 'Festivais de Lisboa' (anos}

60)

A história dos festivais de cinema em Portugal tem necessariamente que passar pela referência, ainda que breve, ao papel dos cineclubes na criação de espaços de exibição, circulação e fruição de filmes. No período do pós-guerra, sedimentou-se, na europa, o cineclubismo e a crítica de cinema. A arte cinematográfica foi reabilitada, já não por protagonistas pertencentes a universos artísticos externos ao cinema (mais legítimos e autónomos), mas por "cinéfilos", que Duval e Mary $(2006,7)$ descreveram como "uma pequena fração da juventude pequeno-burguesa (...) que se caracteriza pela frequência assídua dos cinemas, cineclubes e cinematecas", constituindo públicos que "desenvolveram uma relação erudita com o cinema" e para os quais o cinema tem uma "história própria." 2

Segundo Paulo Granja, os cineclubes nacionais surgiram como uma reação legitimista, numa fase em que a americanização do consumo de cinema e a confluência entre as esferas literária e cinematográfica tinham transformado o cinema numa verdadeira "indústria cultural e espectáculo de massas", o que resultou na larga frequência das salas de cinema pelas "classes médias urbanas" (Granja 2007, 364). As elites culturais de "cinéfilos" procuraram contrariar esta massificação e indiferenciação. Organizados em moldes associativos, esforçaram-se por "desenvolver nos seus associados, através da exibição e da discussão de filmes considerados dignos de apreciação estética, competências culturais específicas de

\footnotetext{
2 É essa a época da "política dos autores" francesa, de que foram protagonistas os críticos da revista Cahiers du Cinèma e futuros autores da Nouvelle Vague (Truffaut, Godard, Chabrol, Rivette ou Rohmer), e que favoreceu o aparecimento de realizadores como Tati ou Bresson (Mary 2006). Os estetas da "política dos autores" reivindicavam a necessidade de legitimar o cinema a partir de critérios intrínsecos a esta expressão artística.
} 
interpretação do cinema como arte" (Granja 2007, 364). As duas primeiras associações cinematográficas de espectadores foram criadas em 1924 - em Lisboa e no Porto. Chamavam-se ambas "Associação dos Amigos do Cinema". Embora várias outras pequenas iniciativas tenham tido lugar nos anos 1930, convencionou-se que o movimento cineclubista português ter-se-ia iniciado, verdadeiramente, com a criação do Belcine - Clube de Cinema da Parede, em 1943, e do Clube Português de Cinematografia (CPC/CCP), no Porto, em 1945 (Cunha 2013; Granja 2007). As iniciativas portuguesas propunham-se contribuir para a consagração da Sétima Arte e elevar a cultura cinematográfica nacional através da disseminação do "bom" cinema, numa atitude pedagógica marcada por uma "ansiedade de contaminação."3

Quando o movimento cineclubista português entrou em declínio, entre 1950 e 1960, a razão terá sido, em grande parte, as dificuldades levantadas pelo regime e pela censura - repressores e hostis à iniciativa cineclubística e à própria prática cinematográfica (Cunha 2013; Monteiro 2000; Pina 1986). Granja (2007, 381-382) admite que o movimento possa ter sido, ainda, "vítima do seu próprio sucesso": a partir do momento em que passou a atingir franjas maiores de públicos, transformou-se numa prática menos distintiva e exclusivista, e perdeu adeptos entre a elite cinéfila. Por outro lado, a Cinemateca Nacional deu início à sua atividade de programação em 1958.4 É, por isso, crível, que a Cinemateca tenha contribuído para esvaziar a prática cineclubista e associativa na capital.

Podemos dizer que, pelo menos até certo ponto, o despertar do interesse pelos festivais de cinema foi causa e efeito do enfraquecimento do movimento cineclubista. Segundo Pina (1986: 171-172), para a "decadência" do movimento terão contribuído mudanças profundas na sociedade portuguesa, assim como a "concorrência de outras formas de cultura cinematográfica", como a Cinemateca, os cinemas de arte e ensaio, as retrospetivas da Gulbenkian, os ciclos e os festivais de cinema, entre outras iniciativas desenvolvidas ao longo da década de 1960. No mesmo sentido, Acciaiuoli (2012: 219) argumenta que os "Festivais Internacionais

\footnotetext{
${ }^{3}$ Para Luís de Pina $(1986,140)$, terá sido o Cineclube do Porto a propor a melhor atividade pedagógica, iniciando a publicação de uma "inovadora colecção de livros de cinema (os cadernos Projecção, saídos a partir de 1949)." Neste período, surgem ainda outras publicações, ligadas a cineclubes, que foram marcantes para a cultura cinéfila do país, como a revista Imagem, o Boletim Cinematográfico, a Visor, a Celulóide, entre outras.

${ }^{4}$ Para um breve resumo da história da Cinemateca Portuguesa, veja-se: http://www.cinemateca.pt/Cinemateca/Historia.aspx
} 
de Cinema" de Lisboa, juntamente com ciclos temáticos, mostras e semanas dedicadas a cinematografias específicas, procuraram diversificar a oferta de cinema da capital, em resposta a uma "crescente exigência que se havia posto na programação das salas do centro da cidade." ${ }^{5} \mathrm{~A}$ oferta de eventos cinematográficos correspondeu, ainda, a uma estratégia mais ampla para seduzir públicos, numa fase em que se começavam a sentir os primeiros sinais de retraimento do consumo de cinema no circuito comercial (Abreu e Mantecón 2013, 206-207).

Há, portanto, registo de festivais de cinema desde meados dos anos 1960, sobretudo na capital do país - mas, também, noutras das principais cidades, como o Porto, Coimbra ou Guimarães (Cunha 2012) - com cerca de três décadas de desfasamento em relação ao início do fenómeno no continente europeu, numa época em que não existia ainda legislação específica para o setor. Foi também este o período em que se deu uma mudança de política em relação à internacionalização do cinema português, com o aumento da sua representação no circuito de festivais estrangeiros (Cunha 2012, 197). ${ }^{6}$ Os chamados "Festivais de Lisboa" foram iniciativas da associação mutualista Casa da Imprensa e da Corporação dos Espetáculos (um organismo público), e apoiados pela Fundação Calouste Gulbenkian. 0 papel da Fundação Calouste Gulbenkian viria a ser determinante, a partir dos anos 1960, para o Novo Cinema Português e para a cultura cinematográfica nacional (porventura pecando por algum centralismo), com os seus apoios à produção nacional, e a dinamização de inúmeros encontros e ciclos de cinema (Monteiro 2000). Alguns desses festivais eram temáticos, outros alinhavam-se com a orientação de distribuição de determinadas empresas, outros, ainda, reproduziam experiências internacionais. Foi por essa altura que surgiram o Festival do Locutor do Filme Publicitário, o Festival de Filmes de Prevenção de Acidentes do Trabalho, o Festival do Filme Turístico, o Festival de Cinema de Lisboa (Casa da Imprensa) e o Festival do Filme Didáctico, o Festival do Filme Tauromáquico e o Festival Internacional do Filme Agrícola e de Temática Rural, em Santarém (com o apoio da revista de cinema Celulóide), além de inúmeras 'semanas' de

\footnotetext{
${ }^{5}$ A maioria destas iniciativas terá terminado logo na década seguinte, confluindo numa programação contínua na Sala-Estúdio Apolo 70, da responsabilidade de Lauro António (Acciaiuoli 2012, 219).

${ }^{6}$ Nesta altura, e à semelhança do que sucedia na europa, o Novo Cinema Português procurava afirmar-se através de um circuito de divulgação assente nos festivais internacionais. Até então, não existira uma estratégia definida de circulação dos filmes portugueses pelos festivais europeus e as tímidas tentativas de exportação eram tuteladas pelo regime. A diplomacia portuguesa e a presença do cinema nacional no estrangeiro estiveram, por muito tempo, estranguladas pelo contexto de ditadura (Pina 1986; Cunha 2012, 188-189).
} 
cinema estrangeiro (espanhol ou brasileiro, por exemplo). Em 1964, enquanto decorria o I Festival de Cinema de Lisboa no Cinema São Luiz, estreava, no Cinema Europa, o I Festival de Animação, organizado por Vasco Granja (Pina 1986, 174).

Na cobertura que o Diário de Lisboa fez do I Festival Internacional de Arte Cinematográfica (Imagem 1), inaugurado no Cinema São Luís, em 1964, pode observar-se, cristalino, o elogio do evento singular, festivo e imperdível - apanágio deste tipo de manifestações, como forma de gerar nos públicos um anseio de participação (Leão 2006, 2019):

\footnotetext{
Embandeirado e iluminado o São Luiz vestiu galas à altura do acontecimento. Um público numeroso e variado esgotou a sala. Aliás, a sua lotação está esgotada para todas as sessões. (...) Um festival é sempre um acontecimento mundano, mesmo tratando-se de uma iniciativa enquadrada no âmbito da modéstia nacional. (...) Necessariamente a televisão também não faltou. Os seus repórteres registaram o acontecimento, assestando máquinas e projectores sobre a gente conhecida que ia aparecendo. (s/a 1964)
}

Os anos 1960 foram um ponto de viragem fundamental na evolução da sociedade portuguesa, em que se começa a vislumbrar uma mudança estrutural (Costa e Machado 1998, 17). 0 descompasso entre o estádio 


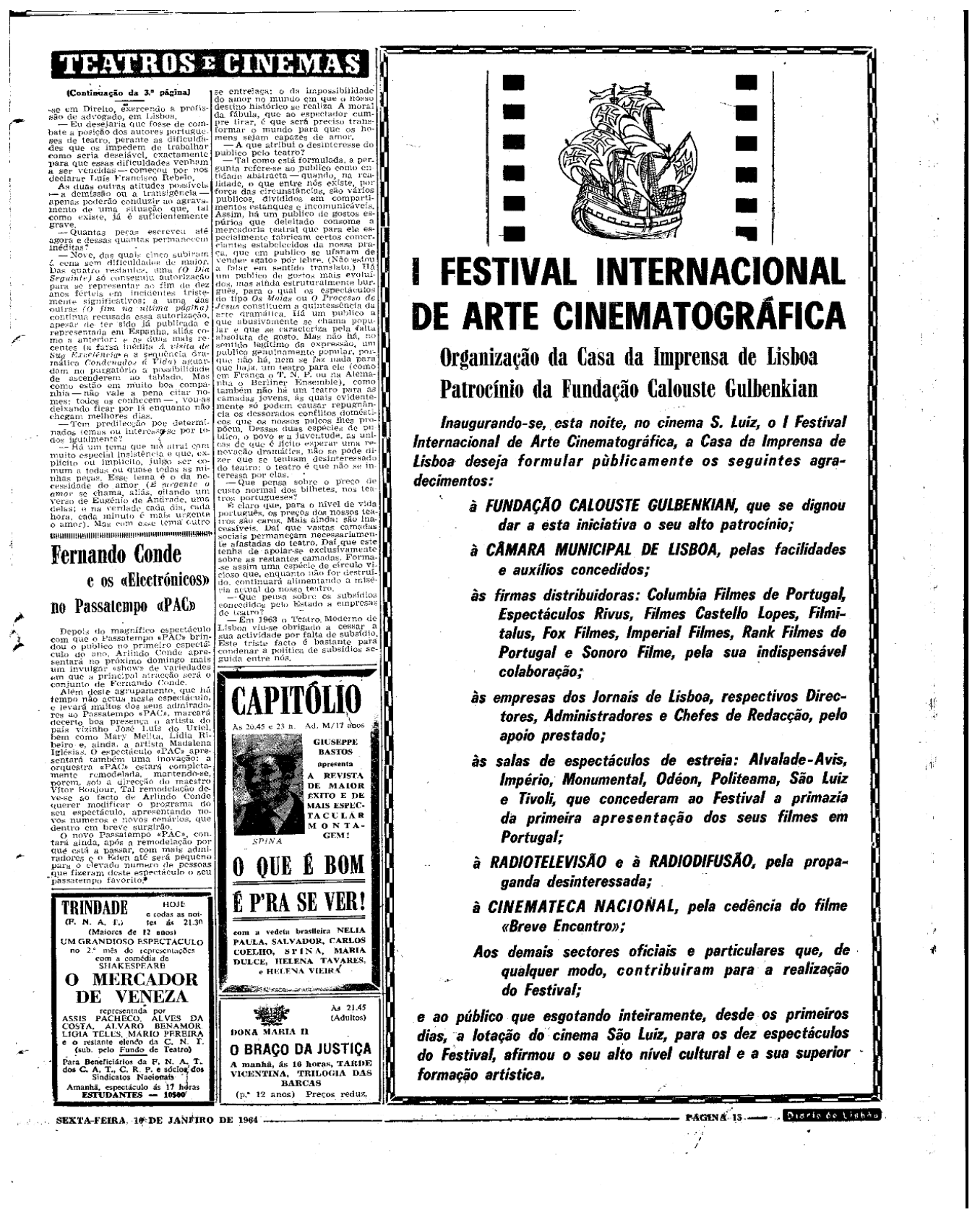

Imagem 1: Publicidade ao I Festival Internacional de Arte Cinematográfica. Diário de Lisboa, janeiro de 1964.

evolutivo de Portugal e o de outros países europeus (que acolhiam festivais de cinema desde os anos 1930 e/ou alimentavam o 'circuito') é explicado 
pelos contornos singulares dessa sociedade. ${ }^{7} 0$ país viveu refém de um regime autoritário entre 1926 e 1974, que exercia um controle apertado e uma forte vigilância sobre todo o tipo de manifestações públicas, entre as quais, as culturais (Abreu e Mantecón 2013, 207). 0 regime arrogava-se “o direito de definir que cultura convém aos portugueses e quais os valores que a devem enformar", o que marcou a ação político-cultural por muitos anos (Santos et al. 1998, 62), constrangendo a liberdade de produção, circulação e consumo de cinema. Como vários autores salientaram, Portugal foi mantendo o tradicionalismo e um corpo de heranças passadas, mesmo quando ensaiava atualizações e ruturas. ${ }^{8}$

Atualmente, apesar da perda da 'aura' do cineclubismo, o seu contributo para a descentralização territorial da oferta de cinema em Portugal e para o acesso das populações a conteúdos não hegemónicos continua a ser importante. Os cineclubes são, muitas vezes, aliados de produtoras e de distribuidoras independentes, procurando garantir visibilidade a obras com pouca circulação. No entanto, na prática, alguns dos cineclubes nacionais têm, hoje, uma programação que é, na sua essência, composta por cinema maioritariamente comercial, acabando por funcionar como uma extensão do circuito comercial e não como uma alternativa válida ao mesmo. Isto sucede, em particular, em zonas onde não existe ou onde é escassa a oferta de salas de exibição comerciais (Cunha 2016).

A sobrevivência dos cineclubes tem sido fragilizada ou até mesmo inviabilizada pelo emagrecimento de recursos humanos e técnicos, como resultado da falta de investimento público - o que debilita as estruturas, tornando-as muito dependentes da iniciativa e do trabalho voluntários (Pereira 2010). 0 apoio público concedido a cineclubes e a associações dedicadas à exibição de cinema conheceu uma drástica redução entre 2001 e 2004, ano a partir do qual não regressou aos valores anteriores. ${ }^{9} 0$ Norte e o Centro do país são as regiões que mais têm beneficiado deste apoio, ao passo que as iniciativas em zonas com menos oferta de cinema (como o

\footnotetext{
7 Boaventura de Sousa Santos definiu a sociedade portuguesa como "periférica de desenvolvimento intermédio", o que traduz a descoincidência entre os padrões de consumo mais avançados e as lógicas de produção equiparáveis às dos países semiperiféricos $(1990,109)$.

${ }^{8}$ Se é indiscutível que "os padrões mais elevados de desenvolvimento vão de par com níveis de escolarização mais altos", como observam Costa e Machado, Portugal fez, durante muito tempo, "figura de exceção" na União Europeia, quando o analfabetismo já era, nesse contexto, um problema residual (Costa e Machado 1998, 24).

${ }_{9}^{9}$ Conclusão baseada em dados fornecidos pelo ICA, respeitantes ao intervalo compreendido entre 2001 e 2014/15. Com a regulamentação da atribuição de apoios para este concurso, verificou-se uma grande contenção nos montantes a atribuir e um esforço no sentido de os uniformizar.
} 
Alentejo ou as Regiões Autónomas) são esporádicas ou mesmo inexistentes. As entidades que continuam a funcionar, no Norte e Centro do país, e que são merecedoras de investimento público, suscitam algumas considerações: (i) é notória a sua proximidade à segunda cidade do país, o Porto (além do Cineclube do Porto, existem, na periferia dessa área metropolitana, os Cineclubes de Vila do Conde, Maia, Feira e Joane); (ii) situam-se, por norma, em cidades mais populosas, capitais de distrito ou sedes de município (ex. Viseu e Guimarães); (iii) há uma propensão para estarem localizados em zonas do litoral do país (ex. Porto, Maia, Vila do Conde e Aveiro).

Alguns dos Cineclubes apoiados por fundos públicos tiveram ou têm ligações a festivais de cinema. A título de exemplo, salientamos o Cineclube de Vila do Conde, na origem do Festival Curtas Vila do Conde; o Cineclube da Feira, ligado à organização do Festival de Cinema Luso Brasileiro; o Cineclube da Horta, que organiza o Faial Filmes Fest; ou o Cineclube de Avanca, ligado à organização do Festival de Cinema de Avanca. 0 mesmo se verifica com as associações apoiadas, que, muitas vezes, apostam na organização de festivais de cinema como uma extensão 'natural' da sua atividade de exibição regular de cinema e - não menos importante - como forma de diversificar as fontes de financiamento público. São vários os exemplos, pelo que destacaremos apenas alguns: a Associação Ao Norte Associação de Produção e Animação Audiovisual, que desenvolve atividade cineclubística em Viana do Castelo e promove a organização do Festival Encontros de Cinema de Viana, na mesma cidade (e, mais recentemente, do Filmes do Homem - Festival Internacional de Documentário de Melgaço, atualmente MDoc, organizado em parceria com a Câmara Municipal de Melgaço); em Lisboa, a Zero em Comportamento - Associação Cultural, que precedeu o IndieLisboa, esteve na sua origem e foi a entidade organizadora do festival durante vários anos; ou, no Porto, a Associação Porto/Post/Doc que se tem dedicado, em simultâneo, à organização de um festival de cinema (o Porto/Post/Doc - Film \& Media Festival) e à dinamização de uma programação de cinema regular na cidade (o "Há Filmes na Baixa!").

A quebra significativa, em Portugal, no montante destinado ao apoio público da atividade de cineclubes e associações coincide com o início da entrada em funções do ICA e com a criação do 'Subprograma de Apoio à Realização de Festivais de Cinema em Território Nacional'. Há uma clara transferência de verbas, de investimento e de públicos para os eventos cinematográficos, pelo que é plausível associar esta mudança a uma 
alteração no paradigma da exibição alternativa de cinema em Portugal e nas políticas públicas.

\section{A década de 70, a Lei do Cinema e a legitimação do formato 'festival'}

A Lei n. ${ }^{\circ} 7 / 71$, de 7 de dezembro, que promulgou as bases relativas à proteção do cinema nacional, referia ser do interesse do país a organização, o patrocínio ou a promoção de festivais de cinema. Durante uma vintena de anos, foi esta a lei que serviu de base ao travejamento jurídico das atividades desenvolvidas no setor do cinema em Portugal, mantendo-se inalterada apesar das profundas mudanças sociopolíticas que, entretanto, ocorreram na sociedade portuguesa (como o fim da ditadura e a posterior integração na Comunidade Económica Europeia). ${ }^{10}$

Alguns dos festivais de cinema nascidos nos anos 1970, já ao abrigo na nova lei, procuraram corresponder ao estímulo para o investimento numa programação que cumprisse parâmetros 'de qualidade', fosse heterogénea, mas com enfoque no cinema nacional. Foi o caso do Festival Internacional do Filme Agrícola e de Temática Rural de Santarém (1971) que, com o suporte da cobertura realizada pela revista de cinema Celulóide, esteve em funcionamento durante cerca de dez anos. Ao longo desse período, o festival contribuiu para a divulgação do cinema português de temática agrícola. Os documentários exibidos cabiam na categoria dos filmes culturais, didáticos ou educativos, na linha dos Kulturfilms alemães, e foram os grandes responsáveis por, juntamente com o espectro mais alargado do cinema científico português, impulsionar o processo de legitimação cultural do cinema em Portugal (Baptista 2018). É também neste intervalo de tempo que surge o FICA - Festival Internacional de Cinema do Algarve, festival generalista nascido em Portimão (1971-2010), o Festival Internacional de Cinema da Figueira da Foz (1972-2002), e o Cinanima - Festival Internacional de Cinema de Animação (1976-), sedeado na cidade de Espinho.

0 acontecimento que, neste período, terá sido o caso mais exemplar de aproximação a uma lógica de programação regida por critérios de

\footnotetext{
${ }^{10}$ A enunciação da importância dos festivais de cinema e de iniciativas similares para a divulgação das atividades cinematográficas e audiovisuais foi reiterada mais de duas décadas depois, em 1993, num documento legislativo que decretava que a sua realização poderia "beneficiar de apoio, nomeadamente de carácter financeiro". No entanto, e apesar do reconhecimento dos festivais como eventos cinematográficos de interesse público, os critérios para a atribuição de apoios públicos a projetos desta natureza não foram formalizados até 2003.
} 
independência e cinefilia, fundamentos análogos aos das salas-estúdio que começaram a proliferar no país em meados dos anos 1960, foi a Semana Internacional da Figueira da Foz (1972) (mais tarde, Festival Internacional). 0 festival da Figueira da Foz, cujo reconhecimento, entre profissionais de cinema, críticos, cineclubistas e público "cinéfilo", ecoa até aos dias de hoje, tinha como objetivo exibir cinema independente, "marginal aos grandes circuitos" (António 1982, 15-16). O certame posicionou-se como um espaço de transgressão e de liberdade de fruição artística, num período em que a censura acinzentava a oferta disponível e asfixiava a possibilidade de debate público. Para o seu mentor, José Vieira Marques, o festival tinha um "papel a cumprir no interior da cultura cinematográfica portuguesa", a efetuar-se através de um trabalho pedagógico de "enquadramento cultural" das propostas de exibição, que incluía "debates, colóquios, textos críticos e de apoio" (António 1982, 15-16). Com esse fim, a organização incitava ao contacto dinâmico entre o público e o cinema (Imagem 2), através de uma programação de qualidade, do debate crítico, reflexivo e democrático, e da sensibilização dos públicos para a importância de aprofundarem a experiência ao longo do ano.

Vieira Marques desejava, ainda, contribuir para desmistificar os preconceitos que persistiam, em Portugal e no meio cinematográfico, em relação aos festivais de cinema:

Os Festivais de Cinema gozam em geral, com maior ou menor (in)justiça, da fama de serem um misto indefinível de feira, de festa, de congresso e de encontro. Esse preconceito tem vindo a ser contestado, de facto, nos últimos anos por toda uma série de novas (e renovadas) iniciativas que procuram pôr no justo lugar as relações filme-público, já que a função essencial de qualquer Festival de Cinema é a de criar ou estimular essas relações. (António 1982, 19)

O Festival da Figueira da Foz veio a ter um grande impacto na criação de outros festivais, sendo de destacar o Curtas de Vila do Conde (Ribas 2012). ${ }^{11}$

\footnotetext{
11 Os fundadores do certame vilacondense assumem que, na base da criação desta iniciativa, esteve, além do desejo de prolongamento da sua experiência cineclubística, o contacto com o 'formato' das curtas-metragens e com a sua liberdade estética, formal e narrativa, no referido festival. Descrevem-no como "o evento cinematográfico com a melhor e mais interessante programação do país", que, apesar de "completamente desorganizado e anárquico" era "influente no circuito cultural”, e caracterizava-se pela "informalidade e pelo fácil acesso aos profissionais do sector" (Leão 2019,148).
} 


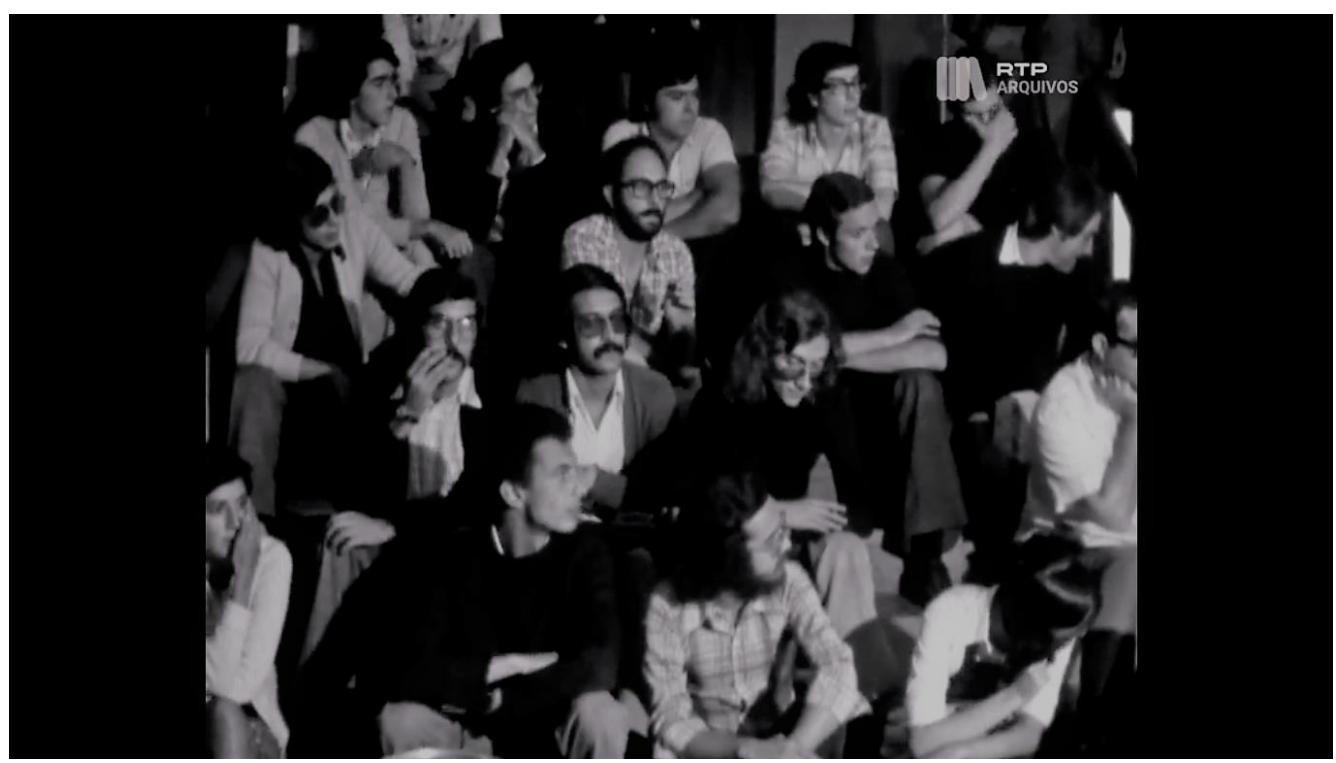

Imagem 2: Público presente na cerimónia de encerramento do Festival de Cinema da Figueira da Foz de 1975. Still do Noticiário Nacional da RTP1 (1975-09-11). (C) RTP Arquivos.

Por fim, fundado em 1976, o Cinanima revelou ser dos festivais de cinema português mais provectos e duradouros - e um dos mais antigos, em todo o mundo, dedicados ao cinema de animação. Dinamizado em Espinho, cidade do distrito de Aveiro, o Cinanima foi um projeto com um objetivo claro de descentralização cultural que ousou especializar-se no cinema de animação. A durabilidade do festival será indestrinçável da constância dos incentivos públicos de que tem beneficiado. Mas, também, da sua influência, sobretudo num primeiro momento, junto dos profissionais de animação portugueses. Abi Feijó, um dos mais conceituados cineastas portugueses de animação, referiu ter sido no Cinanima que descobriu "que a animação podia ser algo artístico", numa altura em que "não havia ninguém a fazer animação em Portugal”. Tal como Feijó que, anos mais tarde, fundou o influente estúdio de cinema de animação portuense Filmógrafo, determinante para a formação de uma geração de animadores nacionais (Martins 2007, 162, 166), outros públicos e profissionais despontaram com o Cinanima.

\section{Os anos 1980: crise no cinema e descentralização dos festivais de cinema}

Após uma curta pausa na retração da frequência das salas de cinema, imediatamente a seguir ao 25 de abril de 1974 - período de euforia, de regresso ao espaço público e à liberdade de poder aceder a conteúdos cinematográficos outrora interditos - os anos 1980 ficaram marcados como 
anos de crise, tendo-se assistido ao encerramento vertiginoso de salas. 0 parque de exibição que existira no país no final dos anos 1970 ficou reduzido a menos de metade. As mudanças económicas e sociais, ${ }^{12}$ a crise interna e a consequente deterioração das condições de vida dos portugueses, a par da cada vez maior influência da televisão e do aparecimento dos filmes em suporte vídeo, conduziram à irremediável quebra do número de espectadores, de recintos e de sessões de cinema (Abreu e Mantecón 2013, 206-209).

Neste período, os festivais de cinema portugueses eram projetos efémeros, transitórios, difíceis de situar: "estas iniciativas têm normalmente curta vida”, proclamara Lauro António (António 1982, 7). E, de facto, assim era. Os festivais que persistiam eram apoiados pelo Estado, sendo notória a tendência, que se começara a esboçar na década anterior, para a sua deslocação para fora dos principais centros urbanos. Ao contrário dos festivais, o grosso dos eventos cinematográficos - ciclos, mostras, encontros, retrospetivas, seminários, debates - mantinha-se excessivamente centrado em Lisboa, "esquecendo-se o Porto e a província" (Pina 1986, 209).

Foi esta a década em que se deu a conhecer o Fantasporto - Festival Internacional de Cinema do Porto, que decorre desde 1981. Produto da vivência cineclubística dos seus fundadores (Mário Dorminsky, Beatriz Pacheco Pereira e António Reis), teve como objetivo especializar-se no subgénero do cinema fantástico. A dada altura, devido à "crise qualitativa" na produção de cinema fantástico, o festival assumiu-se generalista, embora mantivesse a designação original - a sua "imagem de marca"13 - e as ligações ao circuito dos festivais de cinema fantástico, sobretudo por razões estratégicas. Este foi, durante muitos anos, o "maior" festival nacional (com mais frequentadores, mais financiamento do Estado, maior número de sessões e de filmes exibidos). Tornou-se também bastante popular,

\footnotetext{
12 A década de 1980 foi o pináculo de um conjunto de importantes transformações sociais e económicas: decorria, no país, um movimento triplo, de litoralização, urbanização e desruralização; investiu-se mais no ensino verificando-se um aumento significativo do capital escolar médio da população (acentua-se, por exemplo, o crescimento da população estudantil universitária); e assistiu-se a uma recomposição da estrutura de classes da sociedade portuguesa, com o declínio das frações ligadas à agricultura e o crescimento dos assalariados da indústria e dos serviços (Viegas e Costa 1998).

${ }^{13}$ A questão da nomenclatura dos festivais e do modo como esta evoluiu é um espelho da forma como os certames procuraram adaptar-se às novas circunstâncias. Os festivais portugueses, em particular a partir do início do século XXI, começaram a adotar designações em inglês, nomes ou acrónimos mais fáceis de comunicar, e passaram a evitar as filiações demasiado evidentes. Essa foi uma preocupação expressa, por exemplo, pelos fundadores do IndieLisboa, que afirmaram pretender um nome que remetesse ao cinema de arte e ensaio, mas que fosse "suficientemente 'vago' para permitir que o festival se expandisse em diferentes direções" (Leão 2019, 162).
} 
idiossincrático e eficaz no envolvimento dos públicos da região, tendo construído uma forte ligação identitária à cidade do Porto (Leão 2006).14 Uma das especificidades do Fantasporto prende-se com a 'corporalidade' do visionamento dos filmes dos subgéneros fantástico e de terror, visível nas manifestações ruidosas durante as exibições: "(aplaudir a meio do filme, gritar, fazer comentários audíveis para o grupo, interagir com os outros em determinados momentos da acção do filme)" (Leão 2006, 351). Expressões recetivas análogas às assinaladas para os cinemas de bairro do início do século, pouco comuns em festivais nacionais, mas frequentes em festivais do género, como, aliás, demonstra o estudo de Vivar (2016) sobre o Festival de Cinema Fantástico e de Terror de San Sebastian. Nos seus primeiros anos de existência, o Fantasporto foi capaz de apelar aos segmentos mais 'cinéfilos' e eruditos dos públicos, com uma programação ligada ao cinema de autor que evocava a experiência cineclubística dos diretores-programadores. Eventualmente, as opções dos seus programadores e a vivência ritualizada e altamente performativa do certame acabaram por fomentar sentimentos de desconfiança e rejeição nesses nichos do público (Leão 2006).

O Festival Internacional de Cinema de Setúbal (1985-2015) - mais tarde, Festival de Cinema de Tróia ou Festroia - foi outro destacado certame nacional a nascer numa região periférica do país. 0 evento, de escopo generalista, foi idealizado por Manuel Costa e Silva, Mário Ventura e Lauro António. ${ }^{15}$ A missão oficial do festival consistia em divulgar filmes oriundos de países com uma baixa produção cinematográfica. Os júris internacionais que marcavam presença no certame espelhavam essa opção (o festival atribuía os prémios FIPRESCI, da Federação Internacional da Imprensa Cinematográfica, e CICAE, da Confederação Internacional dos Cinemas de Arte e Ensaio). Foi, também, o primeiro - e, durante muito tempo, o único festival português - com acreditação da FIAPF, a Federação Internacional das Associações de Produtores de Filmes. ${ }^{16}$ Porém, aquele que foi, talvez, o

\footnotetext{
${ }^{14}$ Essa eficácia não equivale, porém, a transversalidade, já que os públicos do Fantasporto tendem a ser jovens, com elevados níveis de capital escolar e pertencentes a categorias socioprofissionais (ou em busca de competências escolares) em áreas ligadas a diversos ramos artísticos (Leão 2006, 340). 0 mesmo tipo de seletividade dos públicos foi identificado no Curtas de Vila do Conde e no IndieLisboa (Leão 2019), o que demonstra que a vertente festiva e de celebração não conduz à total indiferenciação dos públicos, pelo contrário - estes apresentam perfis semelhantes ao dos consumidores de atividades culturais.

${ }^{15}$ A primeira edição desenrolou-se num empreendimento turístico de Tróia. Posteriormente, o festival estendeuse à cidade de Setúbal.

${ }^{16}$ Em 2017, já o Festroia tinha terminado a sua atividade, o MOTELx recebeu a acreditação da FIAPF, tornandose o único festival português da atualidade com essa distinção.
} 
principal traço identificativo do festival, foi, paradoxalmente, o interesse mediático gerado pelos atores e atrizes do star system de Hollywood que o visitavam - Kirk Douglas, Lauren Bacall, Dennis Hopper, Jane Russel, entre muitos outros/as (Imagem 3). ${ }^{17}$ Aliás, parte da repercussão do festival, no país e no estrangeiro, ter-se-á devido a esse fator, e ao papel que o certame teve na promoção do país no exterior, e no estreitamento, a pretexto do cinema, das relações internacionais. Outra característica marcante do Festroia foi a forma como investiu na promoção turística da região, à semelhança do que fizeram, ao longo do tempo, vários outros festivais internacionais. ${ }^{18} \mathrm{~A}$ perceção da possibilidade de ganhos económicos com o turismo materializa-se, muitas vezes, na escolha do(s) lugar (es) dos festivais - o Festival da Figueira da Foz já ensaiara tal ligação, mas esta foi mais assumida e evidente no Festroia.

\footnotetext{
${ }^{17}$ No decurso de uma pesquisa de terreno exploratória durante a 25. a edição do Festroia (Leão 2019), pôde comprovar-se essa ambiguidade, expressa no discurso da direção e secundada pela natureza da cobertura mediática do evento.

${ }^{18}$ A relação entre os festivais de cinema e o turismo é antiga e confunde-se com a sua própria história: a Mostra de Veneza, ao optar pelo Lido para a acolher, foi acusada de ser "um mero produto das necessidades da infraestrutura turística veneziana" (Taillibert 2009, 15). Wong salientou que, no período da Grande Depressão, "hospedar um festival de cinema glamoroso num resort durante a época baixa era uma boa ideia de negócio (...) e um contributo para a glória nacional" (2011, 10-11) - razão de ser, igualmente, de Cannes na Riviera francesa, por exemplo. Esta tendência prolongou-se no pós-Segunda Guerra Mundial, com a criação de festivais em Locarno, Karlovy Vary ou San Sebastian, entre outros locais, que escapavam às grandes capitais (Wong 2011, 11). Mais tarde, em 2000, a transição do festival de Berlim do cinema Zoo Palast para a Postdamer Platz, é exemplo de uma ação de marketing urbano, num período em que a competição entre cidades começou a acentuar-se como reação à globalização (De Valck 2007, 75-77).
} 


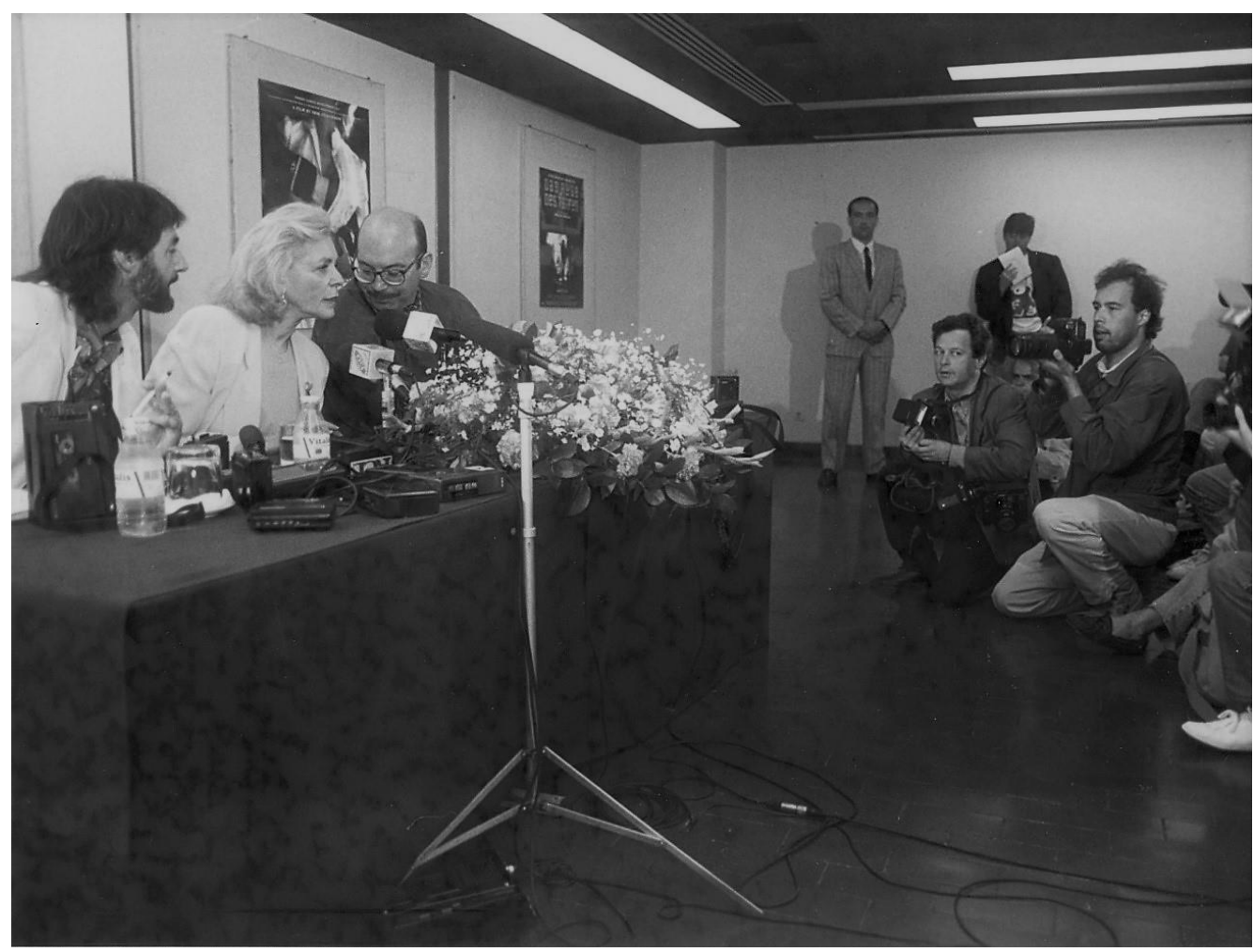

Imagem 3: Lauren Bacall na conferência de imprensa do Festival de Cinema de Tróia, em junho de 1993. (c) Fernando Farinha/ Festróia.

No entanto, o festival mais distintivo a despontar nesta década fê-lo sob a designação de "Encontros": os Encontros Internacionais de Cinema Documental da Malaposta ou Festival Internacional de Cinema Documental (FICDA), que se realizaram entre 1989 e 2001. O FICDA era organizado pela Amascultura - Associação de Municípios para a Área Sociocultural, no Centro Cultural da Malaposta, e teve como fundador Manuel Costa e Silva (um dos criadores do Festroia), a quem sucedeu Luís Correia. O FICDA especializou-se no documentário, género associado às elites intelectuais, devido ao seu potencial educativo e de experimentação e à ligação à academia. A década de 90 do século passado foi identificada por vários autores como um ponto de viragem para o cinema documental português, devido, entre outros fatores, à consolidação do estado democrático do país, ao aprofundamento da ligação com estruturas de ensino formal e ao aparecimento de eventos cinematográficos dedicados ao género, sendo esta iniciativa identificada como o ponto de partida para essa dinâmica (Carrilho, 2008; Mendes et al. 2013; Rapazote 2006; Soares 2016). Os Encontros atravessaram a década de 1990 e realizaram a sua última edição em 2001, altura em que se estendiam a Faro e à cidade de Lisboa (no cine-Estúdio 222). Este que se tornou o evento de referência para as elites 
cinéfilas e demais agentes culturais, era organizado mais próximo da capital lisboeta, em Odivelas, concentrando uma massa significativa de profissionais do setor, artistas e público cinéfilo. Embora suburbano, tinha uma frequência marcadamente urbana, profissional e especializada, com uma ligação forte ao cinema de arte e ensaio e ao conceito das salas-estúdio. ${ }^{19}$ Nas palavras de Sérgio Tréfaut, o festival era "suburbano no sentido físico das cidades" já que "eram três gatos pingados que iam ver excelentes filmes onde o diabo perdeu as calças" (Mendes et al. 2013, 365). O seu impacto foi, no entanto, fortíssimo, já que veio a dar origem à Apordoc - Associação Pelo Documentário, associação cultural sem fins lucrativos, de apoio, promoção e divulgação do cinema documental, que dinamiza, desde 1998, um conjunto de iniciativas de apoio e reflexão sobre cinema documental, entre as quais o incontornável Doclisboa - Festival Internacional de Cinema.

\section{Os anos 1990: festivais especializados como contraponto à 'febre' dos multiplex}

A migração definitiva dos cinemas para os centros comerciais deu-se na década de $1990^{20}$ e correspondeu a uma nova fase de retração das salas ditas tradicionais. Ao mesmo tempo que se assistia ao gradual esvaziamento dos centros urbanos, ${ }^{21}$ era subtraída às salas de cinema a dimensão ritual e socializadora introduzida pelos "cinemas de estreia", nascidos entre os anos 1920-1930 (Baptista 2007). Este fenómeno, que empurrou a exibição de cinema para a periferia das grandes cidades, praticamente circunscreveu a oferta de cinema a salas integradas em complexos comerciais,

\footnotetext{
${ }^{19}$ A salas-estúdio estrearam a introdução, nas salas de exibição de cinema comercial, de programações que obedeciam a rigorosos critérios de exigência. À partida, o termo "estúdio" granjeava, por si só, um público mais cinéfilo, mais próximo da experiência das salas de art house ou de "arte e ensaio" que nasceram, a partir dos anos 50, em alguns países europeus. A partir dos anos 60, apareceram, em Portugal, várias salas que se autodenominavam “Estúdio". É o caso, na década de 60, do Estúdio (da Sala Império) e do Estúdio 444, em Lisboa, e do Estúdio, no Porto. E, nos anos 70, do Estúdio Apolo 70, em Lisboa, do Estúdio Foco e do Estúdio 400, no Porto, e do Estúdio Santa Clara, na Póvoa de Varzim (um dos primeiros a ser inaugurado fora dos grandes centros urbanos). Nos anos 80, nasceram vários Estúdios, um pouco por todo o país (Neves 1998, 4).

${ }^{20}$ Embora já existissem algumas experiências de cinemas com mais do que uma sala em centros comerciais lisboetas, aquele que se convencionou ter sido o primeiro complexo de cinemas a inaugurar em Portugal foram as três salas integradas no Centro Comercial das Amoreiras, estreadas em 1985. Em pouco tempo, o fenómeno multiplicou-se (Acciaiuoli 2012, 318).

${ }^{21}$ Entretanto, haviam surgido novos canais de urbanização e migração interna que já não conduziam a população exclusivamente às duas principais cidades do país, Lisboa e Porto (Viegas e Costa 1998, 20-21).
} 
transformando a relação com esta prática e com o objeto fílmico. A experiência social e cultural de ida ao cinema banalizou-se..$^{22}$

Em reação à proliferação de complexos de cinema em centros comerciais, que propunham cinema de origem maioritariamente norte-americana, verificou-se a instituição de salas com programações alternativas. Foi neste contexto que Paulo Branco se impôs como o dinamizador de um conjunto de salas com uma oferta distintiva, ganhando reconhecimento como o "formador de uma geração de cinéfilos" (Ribas 2014). Branco foi pioneiro na divulgação de cinema português e de filmes de autor em salas comerciais, procurando fazer coexistir a dimensão comercial com "a procura da satisfação de um público mais cinéfilo" (Mendes et al. 2006, 440). 0 produtor e empresário criou e geriu, em simultâneo, várias empresas produtoras, promotoras e distribuidoras de cinema, além da exibidora Medeia Filmes, permitindo que se falasse numa "marca Paulo Branco", unificadora de um conjunto de ações. Em 2006, veio a criar o Estoril Film Festival (futuro LEFFEST), que pretendia ser "um grande festival a nível europeu sediado em Portugal", com notoriedade internacional e "uma abrangência maior em termos de público e conceito" (Mendes et al. 2006, 442-443).

Em comparação com as precedentes, esta foi a década mais propícia ao nascimento de festivais de cinema que reúnem, desde então, um maior registo nos dados do ICA. Terão sido, pois, anos fundamentais para o despertar do interesse - público, mas também político - por este tipo de evento, em Portugal. Uma particularidade dos certames surgidos nesta época consistiu no facto de os mais importantes terem nascido fora $d a$ região de Lisboa, com o apoio de fundos públicos. Outra característica foi a tendência para serem eventos de menores dimensões e mais especializados - à semelhança do que sucedeu na europa, na década de 1980 (Wong 2011, 51-59) -, que optavam por se afastar do modelo do festival genérico ou generalista que definiu os primeiros projetos e que, pelo contrário, investiam num dado género cinematográfico ou em formatos/ suportes específicos.

\footnotetext{
220 aparecimento dos complexos comummente designados de multiplex levou, juntamente com a ténue reconquista de recintos para exibição de cinema, ao aumento do número de ecrãs de cinema disponíveis. A tentativa de racionalização dos recursos incentivou a concentração empresarial (a criação de oligopólios de distribuição e exibição de cinema), a concentração geográfica (a litoralização da oferta) e o afunilamento e uniformização dos conteúdos ofertados (Abreu e Mantecón 2013, 201).
} 
Assim, a região Norte viu aparecer, a título de exemplo, o Curtas Vila do Conde (desde 1993), no município homónimo; o Festival Luso Brasileiro (desde 1996), em Santa Maria da Feira; e o FAMAFEST (1998-2010), em Vila Nova de Famalicão. Na região Centro do país nasceram projetos como o Caminhos do Cinema Português (desde 1994), em Coimbra; o CineEco (desde 1995), em Seia; o Ovarvídeo (1996-2010), no município de Ovar, o AVANCA (desde 1997), em Estarreja; ou o IMAGO - Festival Internacional de Cinema Jovem (1999-2009), no Fundão, para referirmos alguns dos mais importantes.

Salientamos o Curtas Vila do Conde (Imagem 4) pela posição de destaque que ocupou no panorama dos festivais de cinema nacionais desde a sua criação. Pouco tempo após o nascimento do festival, Augusto M. Seabra atribuía-lhe o estatuto de "plataforma de lançamento" de uma nova geração de autores nacionais, mais "cosmopolita" e sem "nenhum particular espírito de missão em reproduzir uma qualquer imagem dominante do cinema português" (Leão 2019: 149-150). ${ }^{23}$ A 'geração curtas', como ficou conhecida, foi, efetivamente, uma novíssima geração de cineastas nacionais, que iniciou a sua trajetória através da produção de curtas-metragens, e que encontrou, no festival, uma janela de visibilidade (Leão 2019; Ribas 2012). Uma das características mais distintivas desta iniciativa foi, por isso mesmo, a sua abertura ao novo. A começar pelos festivais internacionais que lhe serviram de referência, como os de Oberhausen, Clermont-Ferrand, Tampere ou São Paulo (já que, nas palavras dos fundadores, "não conheciam nenhum 'modelo exemplar' em Portugal"). Desde cedo, o festival mostrou apetência para integrar redes internacionais de exibição e de festivais de cinema (Leão 2019, 146-147).24

\footnotetext{
${ }^{23}$ A 'geração curtas', como ficou conhecida, foi, efetivamente, uma novíssima geração de cineastas nacionais, que iniciou a sua trajetória através da produção de curtas-metragens, e que encontrou, no festival, uma janela de visibilidade (Leão 2019; Ribas 2012).

${ }^{24}$ Passadas quase três décadas desde o seu nascimento, o festival mantém uma elevada proeminência, que se expressa na elevada afluência de públicos, no financiamento estatal ou no reconhecimento nacional e internacional. Para informação mais detalhada sobre o Curtas Vila do Conde ver Neira 2015 e Leão 2019.
} 

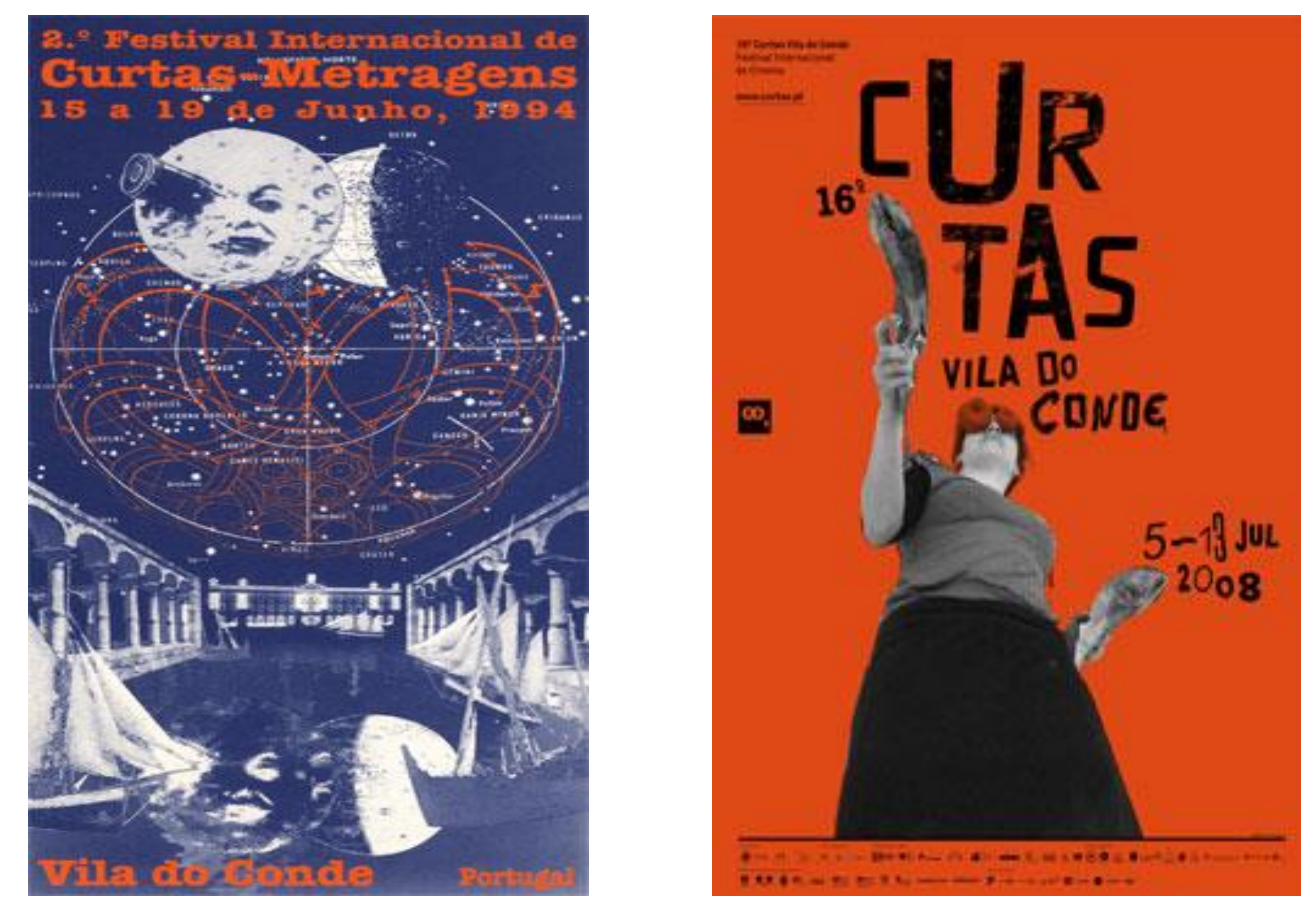

Imagem 4: Cartazes das edições de 1994 e 2008 do Festival Curtas de Vila do Conde. (C) Festival Curtas de Vila do Conde.

Também a capital conheceu o seu primeiro festival de cinema da atualidade nesta década, com o Queer Lisboa, fundado em 1997. 0 Queer Lisboa foi o primeiro - e, até ao momento, o único - festival nacional dedicado à exibição de 'cinema Queer', de temática gay, lésbica, bissexual, transgénero, transsexual, intersexo e de outras sexualidades e identidades não-normativas, sendo contemporâneo dos seus congéneres de Madrid e Paris. O Queer Lisboa respondia às novas reivindicações cidadãs e de direitos humanos de base identitária que se começavam a fazer ouvir, e celebrava uma nova linguagem cinematográfica ligada às identidades sexuais e de género num período em que ainda se sentiam as repercussões da epidemia do VIH, nomeadamente na criação artística. Em 2004, o festival estende-se para o Porto, nascendo o Queer Porto. Uma parte significativa dos projetos que então surgiram terminou. ${ }^{25}$ Outros sobressaíram pela tenacidade, caso do Curtas Vila do Conde, do Festival Luso Brasileiro, do Caminhos do Cinema Português ou do Queer Lisboa. Estes festivais têm, em comum, a especialização/ segmentação da sua oferta, mas, também, o

${ }^{25}$ Foi o caso do VideoLisboa (1999-2005) e do ULISSES (1999-2004), ou ainda, na região do Alentejo do Festival Ambiente - Encontros de Imagem e Som do Norte Alentejano (1998-2003/2007). 
incentivo financeiro ininterrupto do Estado (com a exceção do Caminhos do Cinema Português, que sobreviveu a intermitências no apoio).

\section{Os festivais de cinema na viragem de século: a institucionalização do formato}

O primeiro decénio do novo século conheceu o nascimento de uma quantidade ainda superior de festivais de cinema. Foi nesta altura que se acentuou a institucionalização dos festivais de cinema em Portugal, com a entrada em vigor, em 2003, da regulamentação específica para este tipo de manifestação cultural. ${ }^{26} 0$ regulamento, emitido pelo ICAM, procurava definir um enquadramento legal para a concessão de apoios a entidades promotoras de festivais a realizar em território nacional. Nele, sublinha-se a necessidade de elaborar um conjunto de "regras funcionais de atribuição de apoios", de forma a garantir princípios de "transparência", "igualdade" e "proporcionalidade", que, até então, não se encontravam regulamentados. ${ }^{27}$ Certo é que, nos anos seguintes, continuaram a ser atribuídos apoios a eventos muito díspares, como mostras de cinema, semanas culturais dinamizadas por instituições de ensino superior e outras iniciativas, que pouco tinham a ver com o que se entendia, dentro e fora dos documentos legislativos, por 'festival de cinema'.

Não obstante, as alterações legislativas impulsionaram a modernização e a profissionalização de muitas destas estruturas no país: é a partir desta altura que a capital se vê, novamente, invadida por festivais de cinema (Ferreira 2018; Leão 2019; Miranda 2020; Vale 2013).

Fundados em 2004 e 2002, respetivamente, o IndieLisboa e o DocLisboa foram precursores desta nova vaga de festivais. ${ }^{28} \mathrm{Na}$ primeira metade da década, há ainda a destacar o nascimento do MONSTRA (desde 2000) e do multidisciplinar TEMPS D’IMAGES (desde 2003). Já na segunda metade,

\footnotetext{
${ }^{26}$ Regulamento n. 23/2003, de 26 de maio, que determina o 'Apoio à Realização de Festivais Nacionais'.

270 documento procura delimitar o que se entende por "festival”, avançando com uma definição. Mas não especifica qual o tipo de manifestação a considerar, a sua regularidade ou duração, ficando ainda em aberto a possibilidade de o projeto ser competitivo ou não, aspetos que serão esclarecidos em reformulações posteriores - tais como, a Portaria n.. 499/2004, de 6 de maio, que regulamenta o apoio financeiro à realização de festivais (art. 1, alínea 2) e a Lei n.o 42/2004, de 18 de agosto - 'Lei da Arte Cinematográfica e do Audiovisual'.

${ }^{28} \mathrm{O}$ IndieLisboa foi um dos festivais que analisámos mais aprofundadamente em pesquisa recente. Interessounos, em particular, os seus públicos, mas também os fundamentos para a criação do festival (Leão 2019). Sobre o Doclisboa, cujo relevo no panorama atual dos festivais de cinema é incompatível com uma nota de rodapé, pode ler-se mais nas pesquisas de Carrilho, 2008; Alves, 2018 ou Ferreira, 2018.
} 
surgem, em Lisboa, o MOTELx (desde 2007) e, no Estoril, o futuro LEFFEST (desde 2006). São ainda criados, na região Norte, os Encontros de Cinema de Viana (desde 2000) e o FEST, em Espinho (2004); na região do Alentejo, o FIKE (desde 2002) e o ANIMATU (2004-2009); na Região Autónoma da Madeira, o FICF (2005-2008/2013); e, na Região Autónoma dos Açores, o Faial Filmes Fest (2005-2011).

Mais uma vez, entre os festivais de cinema fundados nesta década, aqueles que se revelaram mais precários foram os afastados de Lisboa e do Porto. Já os que se consolidaram foram os festivais urbanos, com ligação à indústria e um potencial de grande profissionalização (o DocLisboa e o IndieLisboa serão os casos mais evidentes); mas também os festivais programados para 'nichos' de públicos e com circuitos próprios (como o Queer, o MONSTRA ou o MOTELx). Com a exceção do LEFFEST, que veio ocupar o vazio deixado pelo Festival da Figueira da Foz e pelo Festróia, as iniciativas que investiram numa oferta generalista raramente tiveram êxito.

Há uma conjuntura que leva a que estes festivais observem mais facilmente os critérios de elegibilidade para a obtenção de financiamento do ICA, que favorecem a manutenção dos certames que são capazes de se provar 'viáveis', mas estorvam o aparecimento de novos festivais, em circunstâncias que são de grande desequilíbrio. ${ }^{29} 0$ recentramento dos eventos na capital e em algumas das principais cidades do país está fortemente ligado ao acesso a equipamentos culturais detidos ou geridos por entidades públicas (estatais ou municipais): a Cinemateca, o Cinema São Jorge e a Culturgest, em Lisboa, assim como o Teatro Municipal Rivoli, e os cinemas Trindade e Passos Manuel, no Porto, têm sido firmes aliados dos festivais de cinema. Outro aspeto é o acesso privilegiado a estruturas de apoio (como a Casa de Cinema de Lisboa, que acolhe, desde 2013, os principais promotores de festivais de cinema lisboetas), a recursos humanos qualificados e a financiamento privado. A centralização garante uma maior visibilidade mediática e permite alcançar um público (profissional e não profissional) mais numeroso (Leão 2019; Vale 2013, 3941).

\footnotetext{
${ }^{29}$ Existem limiares mínimos de desempenho que são exigidos aos festivais de cinema, a saber: (a) terem, pelo menos, duas edições anteriores consecutivas; (b) a edição anterior ter atingido um mínimo de 5.000 espectadores ou, no caso de o festival decorrer num concelho com menos de 100.000 habitantes, um mínimo de 2.500 espectadores; e (c) a(s) sala(s) ou recinto(s) onde o festival decorreu disporem de um sistema informatizado de gestão de bilheteira.
} 
A evidência de maior investimento público nos certames localizados junto aos dois principais polos urbanos do país tem suscitado críticas aos critérios de atribuição de apoios por parte dos dinamizadores de festivais mais pequenos e descentralizados. Na Lei do Cinema n. ${ }^{\circ}$ 55/2012, que estabelece os princípios de ação do Estado no quadro do fomento, desenvolvimento e proteção da arte do cinema e das atividades cinematográficas e audiovisuais, é referida, expressamente, a "necessidade de ampla fruição das obras cinematográficas nacionais pelo público, em especial nas localidades com menor acesso a salas de cinema" (itálico nosso). $\mathrm{Na}$ realidade, o que se tem verificado é que as populações das localidades protegidas na letra da lei têm-se visto privadas de festivais de cinema, em flagrante contradição com um dos principais propósitos da institucionalização destas iniciativas.

\section{Os festivais de cinema na contemporaneidade: impasses e desafios}

Depois de 2010, os festivais de cinema trilharam o mesmo caminho de outros eventos culturais: aumentaram exponencialmente. A era da "festivalização da cultura" (Bennett, Taylor e Woodward 2014) atingiu o país cerca de duas décadas depois de o fenómeno ser notado noutras áreas do globo. Portugal viu nascer inúmeros festivais de cinema. Uma das características dos festivais mais recentes é o investimento na comunicação. A autopromoção assume uma importância crucial para estes eventos, que, pela sua pequena dimensão ou por serem organizados em contextos precários e de grande informalidade, correm o risco de passar despercebidos. Por serem cada vez mais numerosos, procuram formas criativas de se destacar dos demais. Apesar de não constarem das estatísticas públicas, a pesquisa num motor de busca da internet permitenos entrever o peso que têm no conjunto da oferta de cinema - que é considerável/ elevado. ${ }^{30}$ Esta 'inflação de eventos' comportou prejuízos, como a institucionalização excessiva, a instrumentalização (política e económica) e, por consequência, o esvaecimento da sua razão de ser principal (Taillibert 2009, 34). Vários desafios, entretanto, se colocaram. A banalização de eventos levou a que muitos festivais deixassem de ser peças

$30 \mathrm{Na}$ pesquisa que fez, Barbosa $(2015,43-44)$ isolou, para a janela temporal estabelecida para o levantamento de informação (entre 2013 e 2014), 70 festivais de cinema com, pelo menos, uma secção competitiva. Neste conjunto, incluiu os festivais organizados tanto pelo setor privado não lucrativo como pelo setor público, os festivais responsáveis pela sua própria programação de cinema, e todos os festivais de cinema apoiados pelo ICA. Concluiu existir um número muito significativo de festivais "com apenas uma a duas edições". 
importantes no panorama cinematográfico, tornando-se meros exibidores de cinema para nichos dos públicos, como evidenciara Vallejo (2014). Há ainda a considerar o papel dos festivais de cinema na moldagem de estéticas e cinematografias, cada vez mais premente no meio português, nomeadamente: o facto de a institucionalização dos festivais ter como "efeito secundário", como referiu De Valck (2012, 32-33), a "autorreferenciação", levando a que se programe segundo as expectativas imaginadas dos públicos. Ao fazê-lo, a criação/ produção de cinema tende a adequar-se ao sistema, fomentando a estandardização dos conteúdos. Alguns estudos indiciam uma tendência progressiva para os festivais contemporâneos programarem os mesmos filmes (Vallejo 2020, 5). Por fim, há o problema da hipercompetitividade, num contexto de proliferação de festivais, com consequências negativas para a circulação dos filmes (Leão 2017).

Neste período dá-se a proliferação de formatos e plataformas de distribuição e exibição de cinema na esfera doméstica (a era dos "múltiplos ecrãs"), em sintonia com a crescente privatização do consumo e a diminuição do número de espectadores em sala. A digitalização dos conteúdos, a diversificação dos suportes e dos equipamentos tecnológicos que permitem o acesso ao cinema, a sua portabilidade e a possibilidade de concentração na esfera doméstica, têm tido, como efeito, a transformação do modo como se consomem as criações cinematográficas (Espanha 2007). A nova vaga de reorganização - neste caso, do consumo de cinema - pode ser prejudicial para alguns festivais de cinema, mas não o será para todos. O desejo de partilha, de reflexão e de debate mantém-se entre os consumidores de cinema, mesmo entre aqueles que o consomem, cumulativamente, noutras plataformas (Cardoso e Mendonça 2017; Leão 2019; Vallejo 2014). Os festivais põem em jogo um conjunto de ritos e de dramas rituais, e essa dimensão convida a apropriações ritualistas e conspícuas das obras (Regev 2009, 118-122). Apesar de ser já possível interagir em ambiente virtual, não é garantido que o desejo de consumo presencial saia prejudicado. Os festivais de "negócios" - para utilizar a expressão cunhada por Peranson (2009) - mais profissionais e com uma forte componente de mercado, estão ainda muito dependentes das redes, circuito(s) e sinergias que resultam dos encontros entre os profissionais e as audiências. De resto, a recente 'festivalização' da oferta de cinema, em Portugal, não coloca, automaticamente, o conjunto dos eventos no mesmo patamar. Continua a haver projetos muto diferentes e nem todos têm capacidade de atrair a massa humana responsável por impulsionar a 'cinefilia' e a cultura cinematográfica do país. As instâncias de legitimação 
continuam a ser a crítica especializada, os círculos de pares, os agentes culturais e artísticos, ou seja, todos aqueles que proporcionam às "vanguardas" - "mais não seja através da polémica ou do escândalo" - uma certa forma de "patrocínio simbólico", para empregar palavras de Bourdieu $(1996,287)$. Os agentes de mudança selecionam criteriosamente os festivais de cinema que frequentam, moldando-os, influenciando a opinião pública e as próprias dinâmicas e tendências do setor e da cultura cinéfila.

\section{Considerações finais}

A análise sucinta, que aqui apresentámos, da forma como evoluíram os festivais de cinema, em território português, permitiu concluir, em primeiro lugar, que a ausência da produção de informação rigorosa e de estudos sistemáticos sobre o fenómeno dificulta a reconstituição desta teia complexa - quer no plano diacrónico quer no plano sincrónico. Seria, por isso mesmo, importante investir num levantamento metódico de dados sobre os festivais das décadas mais distantes, mas também sobre os certames contemporâneos, em toda a sua diversidade. Evitar-se-ia, assim, que as pesquisas que agora despontam, se circunscrevam em demasia, como se tem verificado, aos festivais que nasceram nas duas últimas décadas, aos certames lisboetas e/ ou àqueles que são apoiados pelo Estado e sobre os quais existem dados estatísticos. Essa inclinação, embora compreensível, prenuncia a criação de um corpo de conhecimento que não corresponde à heterogeneidade e riqueza do fenómeno em Portugal.

Concluiu-se, ainda, observando a forma como nasceram e evoluíram os festivais de cinema portugueses, que existe uma décalage em relação à realidade europeia - que é, aliás, constitutiva de várias outras dimensões da sociedade portuguesa. Os primeiros festivais de cinema em Portugal datam da década de 1960, cerca de 30 anos após o aparecimento dos precursores europeus. Com o declínio dos cineclubes, dos cinemas de arte e ensaio e dos tempos áureos dos ciclos de cinema na televisão, os festivais de cinema foram ganhando espaço enquanto contextos de perpetuação do encontro entre o filme e o espectador. De resto, estas manifestações têm calcorreado os mesmos patamares evolutivos dos festivais europeus - desde a tendência para a sua segmentação e especialização, seguida da institucionalização, empresarialização e eventual saturação do formato - apenas com o desfasamento temporal referido. Este desfasamento pode ter efeitos positivos, já que permite que os responsáveis pela dinamização de festivais nacionais (e os responsáveis políticos) olhem para os congéneres europeus, não só para anteciparem tendências, mas igualmente riscos. 
Como pudemos verificar, a relação com o cinema alternativo ou de autor foi marcada por alterações nos espaços de exibição: ao longo dos anos, transitou-se entre contextos associativos (como os cineclubes), independentes (os cinemas-estúdio dos anos 60-70 e o ressurgimento recente de salas independentes) e institucionais (por exemplo, os que resultaram do processo de recuperação do parque de teatros e cineteatros municipais). Na verdade, os festivais de cinema portugueses tendem a celebrar o lugar e são, cada vez mais, percebidos pelo poder político como instrumentos de branding e ferramentas de promoção das cidades que podem contribuir para transformar capital simbólico em capital cultural e económico, apesar de existirem poucos dados concretos que consubstanciem essa perceção. ${ }^{31}$

Por outro lado, foi possível convalidar o quão vital é o apoio público à exibição não comercial de cinema para garantir a sobrevivência das estruturas e, consequentemente, o acesso da população a expressões estéticas variadas. Contudo, a dependência deste tipo de eventos cinematográficos em relação aos apoios públicos tem associado um risco: o da subversão do papel de intermediação e democratização cultural previsto na lei. Em Portugal, os festivais contemporâneos não têm servido para colmatar a oferta de cinema em regiões dele carenciadas. Pelo contrário, as assimetrias regionais têm-se vindo a aprofundar cada vez mais. Além disso, os regulamentos para a obtenção de apoio incentivam a profissionalização, a institucionalização e a padronização do formato. Na análise da situação contemporânea, é imperativo que se abandonem silogismos simplistas, como aquele que determina que a oferta corresponde à procura. A oferta também molda a procura - a longo prazo, num efeito de aculturação, e a curto prazo, devido ao efeito mediador da acessibilidade à oferta cinematográfica. É importante compreender em que medida (e em que moldes) os festivais de cinema contribuem para formar públicos para o cinema, treinando o seu olhar para estéticas diversas, desse modo fazendo-os participar do ato de criar ou tornar visíveis novos cineastas, linguagens e cânones cinematográficos (De Valck 2016b; Leão 2006, 2019).

É importante reter, nesta análise, que os festivais de cinema são espaços de negociação de hierarquias e legitimidades culturais, contextos de discussão

\footnotetext{
${ }^{31}$ Esta é uma tendência que vem desde o início da história dos festivais (cf. Wong 2011, 2). Sobre a relação entre cinema e turismo, veja-se, no geral, Stringer (2001, 136-137), e Vale $(2013,34)$ e Almeida $(2016,109-116)$, para o debate recente sobre o caso português.
} 
e reconversão de paradigmas cinematográficos. São também mediadores culturais e lugares de consagração, que influem quer na produção de cinema quer na criação, nos públicos, de disposições específicas para o consumo de cinema. Devem, por isso, ser preservados criticamente, no âmbito de um exercício crítico que não abdica de uma análise aprofundada e multiperspetivada do fenómeno. A análise histórica, política, económica e sociocultural dos festivais de cinema em Portugal é, nessa medida, fundamental, devendo ser empreendida em articulação com as mudanças mais recentes que têm afetado a produção, distribuição, programação/ curadoria, exibição e receção cinematográfica, como, de resto, os vários estudos internacionais que referimos, neste ensaio, têm vindo a sugerir.

\section{Referências}

Abreu, Paula, e Mantecón, Ana. 2013. “A Reorganização da Exibição Cinematográfica no México e em Portugal”. Em Diálogos Urbanos: Territórios, Culturas, Patrimónios, org. Carlos Fortuna, e Rogério Proença Leite, 201-231. Coimbra: Almedina.

Acciaiuoli, Margarida. 2012. Os Cinema de Lisboa - Um fenómeno urbano do século XX. Lisboa: Bizâncio.

Almeida, Carlos. 2016. O Papel dos Festivais de Cinema Portugueses na Atração de Turistas. Dissertação de Mestrado em Marketing e Estratégia. Braga: Escola de Economia e Gestão da Universidade do Minho.

Alves, Catarina. 2018. Estratégias de Comunicação na Divulgação de um Evento Cultural: O Caso do Doclisboa. Relatório de Estágio. Mestrado em Cultura e Comunicação. Lisboa: Faculdade de Letras da Universidade de Lisboa.

Araújo, Milena. 2013. Motivação da Audiência de Festivais de Cinema: Estudo exploratório em Portugal. Dissertação de Mestrado em Marketing. Lisboa: Instituto Superior de Economia e Gestão da Universidade de Lisboa.

António, Lauro. 1982. Figueira da Foz: Dez anos de cinema em festival. Figueira da Foz: Câmara Municipal da Figueira da Foz.

Avelar, Raúl. 2013. A Distribuição de Cinema Português no Espaço Europeu. Dissertação de Mestrado em Cultura e Sociedade na Europa. Lisboa: Faculdade de Letras da Universidade de Lisboa. 
Baptista, Tiago. 2018. "Adolfo Coelho e o cinema agrícola em Portugal". ̀̀ Pala de Walsh. Acesso em Dezembro 2020. http://www.apaladewalsh.com/2018/02/adolfo-coelho-e-ocinema-agricola-em- portugal/

Baptista, Tiago. 2007. "Cinemas de estreia e cinemas de bairro em Lisboa (1924-1932)". Ler História 52: 29-56.

Barbosa, Ana. 2015. Mapeamento e Caracterização dos Agentes Culturais de Exibição Não Comercial de Cinema em Portugal: Construção de um Dispositivo Metodológico. Dissertação de Mestrado em Sociologia. Porto: Faculdade de Letras da Universidade do Porto.

Bennett, Andy, Taylor, Jodie, e Woodward, Ian. 2014. The Festivalization of Culture. Farnham: Ashgate.

Bourdieu, Pierre. 1979. La Distinction: Critique Sociale du Jugement. Paris: Les Éditions de Minuit.

Cardoso, Gustavo, e Mendonça, Sandro. 2017. "Ver Cinema em Portugal: Uma análise sobre os novos e os tradicionais consumos". Relatórios OberCom. Acesso em Dezembro 2020. https://obercom.pt/wpcontent/uploads/2017/06/OBERCOM_2017_Ver_Cinema_PT.pdf

Carrilho, Fernando. 2008. Estruturas de Produção do Documentário Português. Estudo de caso no Doclisboa, festival internacional de cinema documental de Lisboa. Dissertação de Mestrado em Comunicação, Cultura e Tecnologias de Informação. Lisboa: ISCTEIUL.

Coelho, Eduardo Prado. 1983. Vinte Anos de Cinema Português (1962-1982). Lisboa: Ministério da Educação e Cultura.

Costa, António Firmino, e Machado, Fernando Luís. 1998. “Processos de uma modernidade inacabada - mudanças estruturais e mobilidade social". Em Portugal, Que Modernidade?, organizado por José Manuel Leite Viegas, e António Firmino da Costa, 17-44. Oeiras: Celta.

Costa, João Bénard. 1986. "Quesitos Sobre a Distribuição e Exibição: Prejudicados com as respostas". Em 70 Anos de Filmes Castello Lopes, organizado por Luís Pina, João Bénard Costa, Manuel Cintra Ferreira, Fernando Lopes, e José Manuel Costa, 19-31. Lisboa: Cinemateca Portuguesa.

Costa, João Paixão. 1999. "Anos 70: Distribuição e Exibição de Cinema Europeu em Portugal". Revista de Humanidades e Tecnologias 2: 5154. 
Cunha, Paulo. 2012. "Os festivais de cinema na internacionalização do Novo Cinema Português (1949-80)". Em Cinema em Português - IV Jornadas, org. Frederico Lopes, 187-199. Covilhã: LABCOM.IFP.

. 2013. "Cineclubismo e Censura em Portugal (1943-65)". Em Atas do II Congresso Internacional História, Literatura e Arte no Cinema em Espanhol e Português, editado por Emma Camarero Calandria, e Maria Marcos Ramos, 381-389. Salamanca. Centro de Estudos Brasileiros da Universidade de Salamanca.

. 2016. "Cinema de Garagem: Distribuição e Exibição de Cinema em Portugal”. Em Cinema em Português - VII Jornadas. org. Frederico Lopes, Paulo Cunha, e Manuela Penafria, 117-137. Covilhã: LABCOM.IFP.

de A., M. 1964. “'Dulcineia' imita Joana d'Arc". Diário de Lisboa, 5.

de Valck, Marijke. 2007. Film Festivals: From European Geopolitics to Global Cinephilia. Amesterdão: Amsterdam University Press.

. 2012. "Finding Audiences for Films: Festival Programming in Historical Perspective". Em Coming Soon to a Festival Near You: Programming Film Festivals, ed. JeffreyRuoff, 25-40. Great Britain: St. Andrews Film Studies.

. 2016a. "Introduction: What is a film festival? How to study festivals and why you should". Em Film Festivals: History, Theory, Method, Practice, org. Marijke de Valck, Brendan Kredell, e Skadi Loist, 1-11. Londres: Routledge.

. 2016b. "Fostering Art, Adding Value, Cultivating Taste: Film Festivals as Sites of Cultural Legitimization". Em Film Festivals: History, Theory, Method, Practice, org. Marijke de Valck, Brendan Kredell, e Skadi Loist, 100-116. Londres: Routledge.

Dias, Cristina Pimentel. 2009. IndieLisboa: A (in)visibilidade do cinema independente. Dissertação de Mestrado em Comunicação, Cultura e Tecnologias da Informação. Lisboa: ISCTE-IUL.

Duval, Julien, e Mary, Philippe. 2006. "Retour Sur un Investissement Intellectuel”. Actes de La Recherche en Sciences Sociales 161-162: 59.

Espanha, Rita. 2007. "Cinema em Ecrãs Privados, Múltiplos e Personalizados. Transformação nos Consumos Cinematográficos". Research Report - OberCom, Acesso em Dezembro 2020. https://obercom.pt/cinema-em-ecras-privados-multiplos-e- 
personalizados-transformacao-nos-consumos-cinematograficosdez2007/

Ferreira, António. 2018. Os Festivais de Cinema em Portugal: Estudo de caracterização e o seu contexto no panorama português. Dissertação de Mestrado em Comunicação, Cultura e Tecnologias de Informação. Lisboa: ISCTE-IUL.

Granja, Paulo. 2007. "Cineclubes e cinefilia: entre a cultura de massas e a cultura de elites”. Estudos de Século XX 7: 361-384.

Mauss, Marcel. 1985. Sociologie et Anthropologie. Paris: PUF.

Leão, Tânia. 2006. O Fantástico e os Seus Públicos: O Festival Internacional de Cinema do Porto Como Espaço Multivocal. Dissertação de Mestrado em Comunicação, Cultura e Tecnologias da Informação. Lisboa: ISCTE-IUL.

. 2007. “O(s) Público(s) do Fantasporto: Perfis-tipo de modalidades de apropriação ritualista do Festival Internacional de Cinema do Porto". Trajectos 11: 31-44.

. 2007/2008. “O Fantástico em Análise: Algumas notas sobre o estudo compreensivo da 23. a edição do Fantasporto". Sociologia: Revista da Faculdade de Letras da Universidade do Porto 17-18: 81-109.

. 2017. "O formato 'festival' em questão". Atas do VII Encontro Anual da AIM. Editado por Ana Balona de Oliveira, Catarina Maia e Madalena Oliveira, 63-73. Lisboa: AIM.

. 2019. Públicos de Festivais de Cinema em Portugal: Um estudo comparado. Tese de doutoramento em Sociologia: Cidades e Culturas Urbanas. Coimbra: Faculdade de Economia da Universidade de Coimbra.

Mary, Philippe. 2006. "Le cinéma de Jacques Tati et la 'politique des auteurs'”. Actes de La Recherche en Sciences Sociales 161-162: 4-9.

Martins, Índia Mara. 2007. “Entrevista a Abi Feijó”. Doc-Online 2: 162-178.

Miranda, Marta. 2020. Public Policies for Cinema in Portugal: The noncommercial film exhibition sector. Dissertação de Mestrado em Economia. Porto: Faculdade de Economia da Universidade do Porto.

Mendes, João Maria; Pereira, Carlos; Jácome, Jorge; Simões, Marta; Cipriano, Miguel; Dias, Vanessa Sousa; Reia-Baptista, Vítor; Moeda, José; Lemière, Jacques; Beleza, Joana; Mata, André Gil; Alan, René; Moreira, Helder; Oliveira, Rosário; Queirós, Lídia; Simões, Pedro Vaz; Rato, José; Trindade, Guilherme; Martins, Levi; Matos-cruz, José; Monteiro, 
João César; Costa, Pedro; Gouveia, Jorge de Sá; Leite, Paulo; Chinita, Fátima; e Falcão, Luís. 2013. Novas e Velhas Tendências no Cinema Português Contemporâneo. Lisboa: Gradiva.

Monteiro, Paulo Filipe. 2000. "Uma margem no centro: A arte e o poder do 'novo cinema'". Em O Cinema Sob o Olhar de Salazar, coordenado por Luís Reis Torgal, 306-338. Lisboa: Círculo de Leitores.

Neira, Fernando Redondo. 2015. "Festivales de Cine y tendencias de futuro. Un estudio de caso". Opción 1: 620-633.

Neves, João Gaspar. 1998. Práticas Distintivas de Exibição Cinematográfica: O caso das salas-estúdio. Dissertação de Mestrado em Comunicação, Cultura e Tecnologias de Informação. Lisboa: ISCTE-IUL. 2000. "Os cinemas-estúdio dos anos 60-70: novas salas, novos públicos, novo cinema”. Boletim OBS 7: s/p.

Neves, José Soares, e Santos, Jorge Alves. 2011. Estatísticas Culturais do Ministério da Cultura - 2009. Lisboa: Observatório das Actividades Culturais.

Peranson, Mark. 2009. "First You Get the Power, Then You Get the Money: Two Models of Film Festivals". Em Dekalog3, editado por Richard Porton, 23-37. Londres: Wallflower Press.

Pina, Luís. 1986. História do Cinema Português. Lisboa: Publicações EuropaAmérica.

Ramos, Felicidade. 2010. Eventos Culturais e Cidades: O caso específico do Curtas Vila do Conde. Dissertação de Mestrado em Ciências da Comunicação: Especialização em Cultura, Património e Ciência. Porto: Faculdade de Letras da Universidade do Porto.

Rapazote, João. 2006. Territórios Contemporâneos do Documentário. O Cinema Documental em Portugal de 1996 à Actualidade. Dissertação de Mestrado em Antropologia. Lisboa: FCSH-UNL.

Regev, Motti. 2009. "International Festivals in a Small Country: Rites of recognition and cosmopolitanism". Em Festivals and the Cultural Public Sphere, ed. Liana Giorgi, Monica Sassatelli, e Gerard Delanty, 108-123. Londres: Routledge.

Ribas, Daniel. 2012. "Anatomia de um Festival. Curtas Vila do Conde (19932012)". Em Puro Cinema: Curtas Vila do Conde 20 Anos Depois, Holboom, Mike; Ribas, Daniel; e Seabra, Augusto M., 4-13. Vila do Conde: Curtas Metragens CRL. 
2014. "As novas \& velhas práticas de consumo de cinema". Em Plataforma Barómetro Social. Acesso em Dezembro 2020. http://www.barometro.com.pt/2014/10/05/as-novas-velhaspraticas-de-consumo-de-cinema/

Santos, Boaventura Sousa. 1990. O Estado e a Sociedade em Portugal (19741988). Porto: Afrontamento.

Santos, Maria de Lourdes Lima; Antunes, Lina; Conde, Idalina; Costa, António Firmino; Freitas, Eduardo; Gomes, Rui; Gonçalves, Carmo; Gonçalves, Helena Seita; Lopes, João Teixeira; Lourenço, Vanda; Martinho, António; Martinho, Teresa; Neves, José Soares; Nunes, João Sedas; Pegado, Elsa; Pires, Isabel; e Silva, Francisco. 1998. As Políticas Culturais em Portugal: Relatório Nacional. Lisboa: Observatório das Actividades Culturais.

Stringer, Julian. 2001. "Global Cities and the International Film Festival Economy". Em Cinema and the City: Film and Urban Societies in a Global Context, editado por Mark Shiel, e Tony Fitzmaurice, 134-146. Oxford: Blackwell.

Soares, Ana Isabel. 2016. "Cinema Português/ Cinema Literário?" Aniki: Revista Portuguesa da Imagem em Movimento 3 (1): 46-63.

S/A (1964). "Luzes de Festival”. Diário de Lisboa, 5.

Taillibert, Christel. 2009. Tribulation Festivalières. Les festivals de cinema et audiovisuel en France. Paris: L'Harmattan.

Vale, Ana. 2013. Festivais de Cinema em Lisboa: Organizações e relações com a cidade. Dissertação de Mestrado em Gestão Cultural. Lisboa: ISCTEIUL.

Vallejo, Aida. 2014. "Festivales cinematográficos. En el punto de mira de la historiografia fílmica." Secuencias 39: 11-42. . 2020. "Changes and Challenges for Documentary and Film Festivals." Em Documentary Film Festivals 2, editado por Aida Vallejo e Ezra Winton, 13-21. Londres: Palgrave Macmillan.

Vivar, Rosana. 2016. "A film bacchanal: Playfulness and audience sovereignty in San Sebastian Horror and Fantasy Film Festival". Participations. Jounal of Audience \& Reception Studies 13 (1): 234-251.

Wong, Cindy Hing-Yuk. 2011. Film Festivals: Culture, People and Power on the Global Screen. New Brunswick: Rutgers University Press. 


\section{Towards an analysis of film festivals in Portugal: genesis, institutionalisation and challenges}

ABSTRACT This essay analyses the birth and evolution of film festivals in Portugal in two steps: (i) by engaging with a literature review that allows us to identify the main existing gaps and point out research possibilities; and (ii) by developing a diachronic itinerary that mobilises multiple dimensions of analysis to underline the complexity of film festivals as a phenomenon shaped by historical, political, economic, social, territorial/ spatial and cultural factors. The analysis seeks to frame the genesis and evolution of Portuguese film festivals within the country's historical and political context. The text thus discusses the relationship between the gradual proliferation of film festivals in Portugal and the observed transformations in cinema exhibition spaces, public policies (particularly, in the legislation applicable to the alternative exhibition circuit), and the growing perception of festivals as drivers of local development. It also highlights the reconfiguration of the circuits of consumption/ fruition of cinema, alerting to the worsening of territorial asymmetries within the cinematographic offer. In the end, I stress the importance of film festivals as decisive contexts for the creation and maintenance of film communities, as meeting places for cultural intermediaries and professionals, and as agents that promote cinema and cinematographic culture.

KEYWORDS Film festival studies; Portuguese film festivals; public policies; film exhibition circuits; film communities.

Recebido a 15-07-2020. Aceite para publicação a 3-01-2021.

anikiDossier temático: Festivais de Cinema | Special section: Film Festivals 